\title{
The Ethiopian Peoples' Revolutionary Party (E.P.R.P.) Formation, Structure and Program
}

\author{
Ayenew Mammo Seyoum (PhD) \\ Debre Markos University, Ethiopia
}

\begin{abstract}
The main aim of this Article is assessing the Ethiopian Peoples' Revolutionary Party (EPRP) Formation, Structure and Program.It also tries to restructure the armed struggle of Ethiopian People's Revolutionary Part (E.P.R.P) in Qwara and Aläfa Takusa district. In fact, it was established in the 1970s by different people of Ethiopians from different areas. And its center was Addis Ababa town and other rural areas. However, in the 1980s its main center was at Qwara and Aläfa Takusa districts. Therefore, this article is aimed at the E.P.R.P military movement was legitimately ongoing in Qwara and Aläfa Takusa district since 1983. In order to undertake this study document analysis, in-depth interview, archival investigation and focus group discussions were undertaken as instruments of data collection. Moreover, I have attempted to use primary and secondary sources. It also attempts to give an analysis of the new party creation in the area. The study also examines the Ethiopian Democratic Union (E.D.U's), one of the opponent parties of the Därg regime, in the area and its structure. The article also attempts to investigate the E.P.R.P and E.D.U temporal alliance and conflict. In the post 1980's, the E.P.R.P had attempted to introduce the new form of approach. The legacy of the party has been encompassed in the article. Furthermore more, the article also attempts to state the final departures of the E.P.R.P, Därg and the coming of Tigrian .People. Liberation Front (TPLF) in the area. This research was undertaken based on descriptive research design. This is because, it helps to achieve the objectives of the study and to find answer to the research questions of the study by allowing the researcher to describe the characteristic of the phenomena understudy and by entertaining the research questions focusing on issues like what, how and who elements.
\end{abstract}

Keywords: EPRP, EDU, Qwara and Aläfa Takusa districts, Därg, T.P.L.F

DOI: $10.7176 /$ RHSS/11-21-02

Publication date: November $30^{\text {th }} 2021$

\section{Ethiopian Political Parties}

The political parties are institutions which struggle to bring change to the community in terms of economic, political and social welfare. ${ }^{1}$ In relation to this, the role of the opposition party in a democracy remains to criticize, check, offer alternative policies and replace the mandatory party with the new mode of administration. ${ }^{2}$

Thus, Ethiopia was adopted a new system of party formation established most dominantly in 1974, that had never seen in the country's history before. ${ }^{3}$ The reason why many party had been established due to the divergent political over view between the Därg and the students movement at the grass root level. ${ }^{4}$

Accordingly, when the government attempts to bring under its control any of the country's economic and political elements, the situation paved the way for the formation of different factions. Consequently, the absence of the participatory system of government denied the peoples political, economic and social freedom. Therefore, the situation gives opportunities to find space to act an armed struggle in the rural areas for different political parties and even the smaller groups. ${ }^{5}$

Ethiopia is the oldest independence country in Africa. Nevertheless, over the last forty years it has been experienced with sever famine, civil conflict and war that devastated the country's economy and undermined stability, and bringing millions to the edge of starvation. ${ }^{6}$ Accordingly, during the period of Haile Selassie I, centralization of power had been continued without the presence of politically legitimate parties. ${ }^{7}$ Hence, since political parties were not allowed to work in the country, opposition forces had been established.

Finally, the imperial rule ended in 1974 after a period of civil unrest and it had been replaced by a provisional administrative council of soldiers, known as the Därg that installed a government which "was socialist in name

\footnotetext{
${ }^{1}$ Merera Gudina, “Party politics, political polarization and the future Ethiopian Democracy, ” Western Michigan University press, (2007),p.3. ${ }^{2}$ Wondosen Teshome, "Ethiopia and opposition political parties and Repel Fronts: past and present," world Academy of Science, Engineering and Technology press, (2009),p.1.

3 Merera,p.2.

${ }^{4}$ Informants: Asmare, Kere, Shambel Zemene Aseged.

${ }^{5}$ Aragawi Berehe, "Apolitical History of the Tigray peoples Liberation Front (1975-1991): Revolt, Ideology and Mobilization in Ethiopia," VRIJE University press,(2008),p.56. : Informant: Alemu Zewude.

${ }^{6}$ Country origin research and information center, “CORI country report: Ethiopia," (2009),p.39-40.

${ }^{7}$ Andargachew Tiruneh, The Ethiopian Revolution (1974-1987), Cambridge University press,(19193),p.231.:Chist Prout and Eugene Rosenfeld, Historical Dictionary of Ethiopia and Eritrea, the Scarecrow press, the Scarecrow University press, (1994),p.38.
} 
and military in style". ${ }^{1}$ Nonetheless, the country has been in unsettled state in the aftermath of the revolution. ${ }^{2}$

Similarly with the Emperor, the Därg was also outlawed all political parties, rebel fronts and established its own, Workers Party of Ethiopia (WPE), to lead the country with the single party state. ${ }^{3}$ Accordingly, "after the Därg, came to power, the state becomes shadowed by the political divergence and an endless political cries". ${ }^{4}$ Consequently, the year 1974 is marked as the beginning of many political parties in Ethiopia. ${ }^{5}$

Some were ethnic-origin rebel fronts based in the neighboring countries and waged guerrilla warfare against the state and others were the multi nationalist groups which made armed struggle inside the urban and rural regions at the initial of its stage. ${ }^{6}$

Accordingly, among the parties that appeared in the Därg period, the one which was pro- Oromo nationalist party which was Marxist in ideology established officially in 1974. Nonetheless, the party started movements secretly several years earlier in $1950^{\text {ee }}$ s called All Ethiopian socialist movement (Me'son in its Amharic Acronym). ${ }^{7}$ It had been managed largely by European minded intellectuals. ${ }^{8}$ Hence, what makes exceptional for all other parties, Me 'son remained "supports of the Därg with criticism". ${ }^{9}$ Besides to this, same individuals said the party as by way of inconsistence party. ${ }^{10}$ So as to solidify the issue more, Hayle Fida the leader of Me 'son after exile, whose aim was to establish a civilian political party, was one of Mengistuees political advisers. Nonetheless, because of his seasonal approach, the Därg was ordered to uproot Me'son and by mid, 1977 thousands of the members had been consumed by the "Red Terror". Besides this the remaining Me'son went to underground, while Hayle Fida becomes arrested and latter executed by the Därg. ${ }^{11}$ Consequently, in line with the above idea, it remained the Eritrean People's Liberation front (E.P.L.F) which took up the armed struggle after September 1961, founded in Cairo, just after the Eritrean federation forwarded by the UN in $1952 .{ }^{12}$

In fact, the Eritrean nationalism was not only cropped up during the armed struggle period, nevertheless, it had been the political seeds which had been planted in the colonial era. ${ }^{13}$ Thus, Eritrean nationalism had a long history, but it remains the E.P.L.F which brought into practices. ${ }^{14}$ Accordingly, during the armed struggle period, E.P.L.F was used the Sahel mountains region in the north part of the country as safe heaven. ${ }^{15}$ The movement was started, because of the founders of the party considered that, as the federation was illegal, as Eritrea also had a colonial question and as it was also needs self-determination. ${ }^{1623}$ Therefore, the party remains commonly called as the secessionist. ${ }^{17}$

Indeed, it stood the emergency of the organization of E.L.M on November 2, 1958, remained put the corner stone to address Ethiopians failure to respect Eritrea's autonomy under Federation. ${ }^{18}$

In relation to the above concept, after many alliances and civil conflict with the E.P.L.F the members of the E.L.M, at the end, many of them becomes ally with E.P.L.F, some also fled to the Sudan, while a few of them surrendered to Ethiopia. ${ }^{19}$ Then, finally after the long period of civil war between the Därg and the E.P.L.F and after the loss of humanitarian and financial resource, E.P.L.F develops won in Eritrea.

Then afterwards the federation took place, "on 24 May 1993, Eritrea officially became an independent state, whom Isaias Afeworki became the countries first president."20

Accordingly, E.D.U (Ethiopian Democratic Union) which had been established after the over through of Emperor Haile Selassie I. ${ }^{21}$ It was organized by a number of the leading figures in the Haile Selassie I government

\footnotetext{
${ }^{1}$ Wondosen, p.1-5.

${ }^{2}$ Harry Brind, Soviet policy in the Horn of Africa, Oxford University, Oxford University press, (1983),p.94.

${ }^{3}$ Bahru Zewude, A History of Modern Ethiopia 1855-199, Addis Ababa, Addis Ababa University press,(2002),p.243-248.

${ }^{4}$ Merera, p.1-25.

${ }^{5}$ Wondosen,p.2.: Merera, p.3.: Informant: Shambel Zemene.

${ }^{6}$ Wondosen, p.2.

${ }^{7}$ Ethiopian peoplee $\mathrm{s}$ Revolutionary party, Ethiopian people"s Revolutionary program,(1975),p.1-25.

${ }^{8}$ Informant: Shambel Zemene.

${ }^{9}$ Informant: Atalay Aseged.

${ }^{10}$ Informants: Shambel Zemene.

${ }^{11}$ Informants: Shambel Zemene, Tegegne Ayalew.

${ }^{12}$ Gilkes,Patrick, Historiography and Mythology, Oxford University, Oxford University press,No.361,Vol.90,(1991),p.23.:Source,stable URL:https://www./jstor.org/stable/722848

13 Gilkes, Patrick, "Historiography and Mythology," Oxford University press,No.361 Vol.90.,(1991),p.6.:Source, stable URL:https://www./jstor.org/stable/722848

${ }^{14}$ Ibid,p, 6 .

15 Reid ,Richard, "Caught in the headlights of history: Eritrea ,the E.P.L.F and the post warnationstate,"CambridgeUniversitypress,Vol.43,No.3,(2205),p.3-7.: URL:https://www.jstor.org/stable/3876064

16 Gilkes, Patrick, “Historiography and Mythology,” Oxford University press,No.361,Vol.90.(1991),p.2. :access, stable URL:https://www./jstor.org/stable/722848

${ }^{17}$ Wondosen,p. 12.

${ }^{18}$ Michael Woldeghiorghis, Eritrean Libration Front Social and Political factors Shaping its Emergency,Development and Demise,"Leiden, the Nether lands, Leiden, the Nether lands press, (2014),p.33.

${ }^{19}$ Ibid,p, 115

${ }^{20}$ Claphan, Christopher, The structure of Regional conflicts in Northern Ethiopia,(Berghahn Books,Vol.13,No.2,(1989)),p.11-20.

${ }^{21}$ Hiwot Tefera, Tower in the Sky, Addis Ababa, Addis Ababa University press,(2012,p.10.:Andargachew, p.174.
} 
of, army, nobility and business groups, established London in 1974. It had been managed with Ras Mengesha Seyum and Nega Tegegne the ex-governor of Bagemder. ${ }^{1}$ The chief motive of the party was to reinstitute the monarchy and its family. ${ }^{2}$

Before the E.P.R.P, it remained the E.D.U which had been almost controlled north western parts of Ethiopian region in general. ${ }^{3}$ The E.D.U was based in Sudan during the period of Nimeiry government ${ }^{4}$ and the American government and others backed the group and the party able to "transmit Ethiopian language broadcasts against the Därg and expressed its policy" from its base. ${ }^{5}$ Accordingly, among other places it remained Tiha that had been the most important training place to the E.D.U. ${ }^{6}$

Accordingly, it was the western Somalia Liberation Front (WSLF) established after the cloth of the Haile Selassie I period. The party was an ethnic based in terms of character and became active during the Därg period. ${ }^{7}$ Since the party served as an agent to the Somalia expansionist government to annex Ogaden and other regions in Ethiopia, it had been supported by the state of Somalia. Its goal was to create the "so-called Greater Somalia based in Ogaden". ${ }^{8}$ Finally, after the military fighting had been done, both the invading army of Somalia and its collaborator were crushed by the Därg.

In line with this, the workers party was the one which was established after 1974. It had been established by different organizations jointly and the Därg by itself had been supported the establishment of the party. ${ }^{10}$ Because the Därg had been assume it as the sympathizer of the state and implemented its policy, while colonel Mengistu was assumed as the chairman. ${ }^{11}$

The main faction among the groups were rely on the question how to they bring the workers party. ${ }^{12}$ Its ultimate goal was to bring malty cultural equality, to recognized the rights of the oppressed people and had expresses its ideas with the paper known to be the "voice of unity." 13 The party was also opposed all the E.D.U, E.P.R.P, T.P.L.F and the Eritrean secessionist group. ${ }^{14}$ Finally, like other party leaders, the fats of the workers party after they disagree with the Därg, some became arrested while some of them join with the other groups. ${ }^{15}$

The other 1974 emergent party was T.P.L.F (Tigray People's Liberation Front). ${ }^{16}$ Its motto was Mahber Gesegesti Behre Tigry ( Tigrayans only for the Tigrayans). ${ }^{17}$ It remained ethno-nationalist and anti-Amhara front. ${ }^{18}$ The dream of the party was to overthrow the military government and establish nation based federalism as languages took as a dividing instrument. ${ }^{19}$ As a matter of fact, the 1995 constitution (Art, 39) also allow unconditional right to self-determination including the right to secession for all nations and nationalities in the country. ${ }^{20}$

Based on the above approach, the party and even the people believe the idea of "Only the Tigrayans could solve Tigrayan problems", and the party was able to mobilized people largely in Tigray. ${ }^{21}$ The Därg on its part, was blamed it as a shifta or bandit. ${ }^{22}$ Bay and large, compared to other parties it was the T.P.L.F which was able to form a state in May1991 after sixteen year of civil war with the Därg and other off its faction. ${ }^{23}$ Hence, the country's prime minister after a while become Meless Zenawi who condemned by many historians, due to

${ }^{1}$ CGAC,Folder no,Täräf Tibäkana lieloch Gudayoch,file 35 Silä täräf märäjawoch tsätita,from colonel Fiqire Abebe to Brigadel General Birhanu Tefera, Ref no 418/9/100,Oän Tikimit 24 1968, Andargachew, p.174.

${ }^{2}$ Informants: Tagele, Alemu, Alemu Aseged, Kere.

${ }^{3}$ Fäntahun Ayele, Ethiopian army from victory to defeat, $\mathrm{S}^{\mathrm{t}}$ Mary University, $\mathrm{S}^{\mathrm{t}}$ Mary University press (2018),p.135. : Informants: Atalay, Tagele, Alemu, Alemu Aseged.

${ }^{4}$ Kiflu Tadesse, Yatiwuled, Vol.3,(1993),p.61. :Historical Dictionary of Ethiopia and Eritrea Informant: Atalay.

${ }^{5}$ Dawet Wälde Giorgis, Yädäm Enba, Alifa printing press,(---),p.145.

${ }^{6}$ CGAC,Folder No 5,Yä çliga Awuraja Tsätita,yä 1975 yä çliga Awuraja Mätsa tsafia Dose, from Shambel Fentaye Eshitie to the kifle hager Astedader,Ref No/71/02/14-7/T/75, qän December 3/02/1975.

${ }^{7}$ Wondosen, p. 495.

${ }^{8}$ Informant: Shambel Zemene.

${ }^{9}$ Informants: Shambel Zemene: Tegegne.

${ }^{10}$ Wondosen, p. 256

${ }^{11}$ Informant: Shambel Zemene.

${ }^{12}$ Ibid.

${ }^{13}$ Informant: Shambel Zemene.

14 Ibid.

${ }^{15}$ Ibid.

${ }^{16}$ Paulos Milkias, Ethiopia, the T.P.L.F, and the Roots of the 2001 political Turmoil, Michigan, Michigan University, University press, Vol.10, No.2,(2003),p.4

${ }^{17}$ Paulos,p.3.

${ }^{18}$ Kassay Abirha, Yasimba Fiqir, Tesfaye Wälde Giorgis Haile printing press,(2005),p.171-172.

${ }^{19}$ The Federal Democratic Republic of Ethiopia: House of peoples representative, The constitution of the Federal Democratic Republic of Ethiopia, Addis Ababa, No.1, (1995),p.32.

${ }^{20}$ The Federal Democratic Republic of Ethiopia: House of peoples representative,p.96.

21 Young, John, The Tigray and Eritrean people"s Libration fronts: a History of Tensions and Pragmatism,Cambridge,CambridgeUniversitypress,Vol.34,No.1,(1996),p.10;access;;StableURL:https://www.j stor.org/Stable/161740

22 Young, John, "The Tigray and Eritrean people ${ }^{\text {ee }}$ Libration fronts: a History of Tensions and pragmatism,"CambridgeUniversitypress,Vol.34,No.1,(1996),p.8; access URL:https://www.jstor.org/Stable/161740.

${ }^{23}$ African Watch Report, "Evil days, 30 years of war and Famine in Ethiopia,"(September,1991),p.9. 
his approval of the independence of Eritrea without any precondition. ${ }^{1}$ Therefore, the history of Ethiopia during the 1970s of the Emperor period in particular and the Därg time in general, known with full of civil conflict and political tension.

\section{The Formation of E.P.R.P}

The need for a well-organized political party has been among the very pre-requisite necessity condition in the Ethiopian political struggle. Then the politico-economic crisis in the imperial regime was ignited by the student revolutionary movement. It was the 1960 failed coup d'état lead by the two Neway brothers, Germame and Mengistu had been the stepping stone for the emergency or the beginning of the new era in the history of the country among other extraordinary factors. ${ }^{2}$ Because, the coup had been showed the students the way how to change the king. ${ }^{3}$

Hence, in January, 1967 USUAA (the university student union of Addis Ababa) became institutionalized by the student to add initiative on the revolution and the "students defended and shielded the union like the mother protected her child". ${ }^{4}$ In relation to the above concept, the event which solidified and exacerbated the intellectual's movement in general and the students union in particular was the murder of Tilahun Gizaw by the Därg on December 28, 1969, whom he was a student activist and the president of the USUAA. ${ }^{5}$ Consequently, one thing which was true that, a number of students had been started going to abroad for scholarship since the national system at home was disturbed by the students. Therefore, the scholars who had been lived abroad had an advantageous for their political activities and become unsafe for the state to continue the struggle within the country and publicized the dictator nature of the government. ${ }^{6}$ Accordingly, as a fashion of the day, the student took Marxism "not only as the only truth but also it colonized them".

Thus, the other students movement which established abroad was ESUE (the Ethiopian Student Union in Europe) and ESUNA (Ethiopian Student Union in North America), played significant role in razing the social and political awareness of university student's and the development of the student movement in the county in general. ${ }^{8}$ Therefore, students in the country and overseas were played their own share in the revolution period.

Apart from stimulating the state to brought transformation, the Ethiopian student union was suffered with the internal division in the meanwhile. Besides to this, the younger radicals were wanted to mobilize the students movement by refusing divisions and increasing public demonstration to address the people in general, while, senior radicals wanted to achieve in favor of organizing and gaining access to the people education and organized themselves. ${ }^{9}$ Therefore, due to the ideal difference, there had been division among students in the country and abroad.

Nonetheless, the division was not limited to the students in the country. Accordingly, among the brain minded student movement leaders abroad, he remained Berhane Meskel Reda who lacking the well strict Marxist-Leninist discipline. ${ }^{10}$ In line with this, the Ethiopian student movement was divided and the division categorized in to three groups. Among the groups, the Algerian collection led by Behane Meskel Reda, ESUE led by Haile Fida in Paris and ESUNA had been led by Senay Likke in North America and the thing that brought controversies or division among them was the article written under the "pen name of Tilahun Takäle" on the national question. Nevertheless both ESUE and ESUNA members assume that, as it was the work of Brhane Meskel. ${ }^{11}$

Therefore, in the time being there had been lack of compromise among different collection leaders abroad which led them to divergence political movement.

Besides to this, the article on the national question which had been drafted and dispatched by the Brhane Meskel groups shifted the student's movement. ${ }^{12}$ Then the event pushed the eleventh ESUE ${ }^{\text {ee }}$ West Berlin congress and then at the congress the participatory showed tendency to the Algeria group. ${ }^{1364}$

Be that as it may, after a while the ESUNA had been held its ninth congress in Los Angeles and officially opposed the Algerian group's national question. ${ }^{14}$ Then taking as an advantage this, the Algeria group becomes

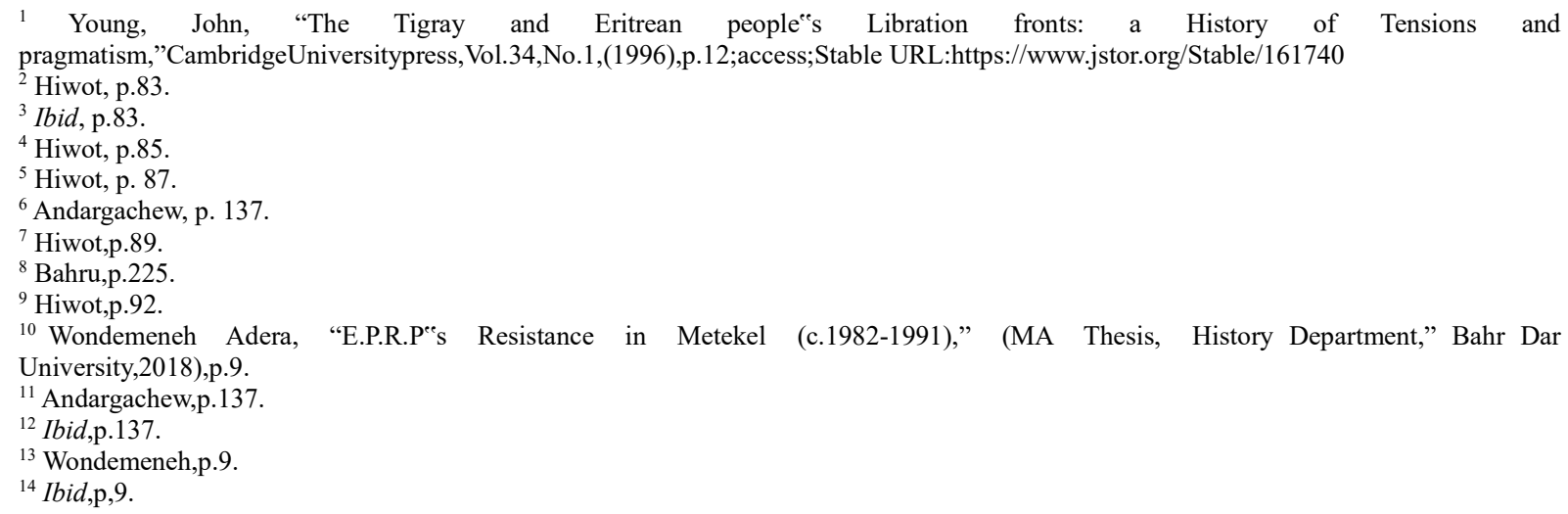


dominant because, it was gain decent supporters on the student movement after a long period of dealing and disagreement. Formerly the Algerian collection had been created the provisional committee in 1971.Accordingly, the "Ethiopian communist party" took as the real name of the party before it named as E.P.R.P. ${ }^{1}$

Besides to this, the E.P.L.O (Ethiopian People's Liberation Organization) which had been establish in Germany since $1972 .{ }^{2}$ Be that as it may, on August 27, 1975, Emperor Haile Selassie Ies power had been expired and after two days E.P.L.O officially by rebranded its name declared as the Ethiopian Revolutionary People's Party (E.P.R.P). ${ }^{3}$ Thus, during the revolutionary period the factions had been cropped up among different groups and it becomes a style.

\section{The structure and the program of E.P.R.P}

The military structure remains the central significant task to understand the cause, conduct and the result of the war. ${ }^{4}$ Accordingly, the military policy remains an integral part of the overall foreign relation and homestead law. ${ }^{5}$ According to Mao-Tse-Tung "the main structure in the organization of the military struggle is the army" ${ }^{6}$ Hence, based on these general over view, the E.P.R.P guerrilla fighters had been organized its military structure after it arrived in Qwara and Aläfa Takusa wäräda. Hence, the military structure of E.P.R.P Armed struggle was also contained both sexes. ${ }^{7}$ Consequently, after the E.P.R.P had been trained about thirteen soldiers in Flistem; the party had been strengthen by the Shabia at Assimba and structured its own military structure. ${ }^{8}$ Thus, the military structure of the E.P.R.P had been central, committee, and, others. Accordingly, Bäkär, Lämma, Alämayähu, Gayim, Dagimawi, Abrham,Dämbälu,Dämälaš,Täsfa yä whose one eye had visionary impaired, Gäbrä Michael were some of male central committees. Though, from among the females sideways Abäbäch, Ayalänäsh, Tirsit, Alimaz, Ayäläch were some of the prominent female commanders. ${ }^{9}$ As one of the interviewee supposed, in Amharic, (Ethiopian National language) it says:



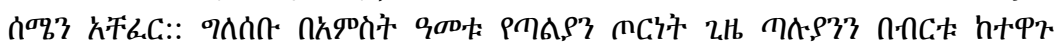

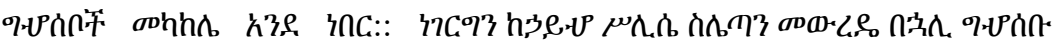

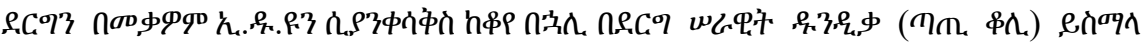

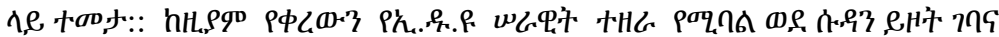

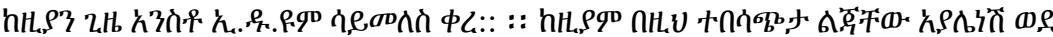

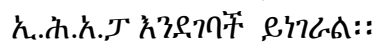

Its translation says: In North Ačäfär there was a man by the name Qäñazmač Semeneh Desta who held important position during the reign of Haile Selassie I. He was one of the Ethiopian patriots who relentlessly fought against the Italians during the period of Italian occupation that lasted for about five years. However, following the deposition of the regime of Emperor Haile Selassie I, he became one of the leaders of E.D.U whom the Därg killed him at Dindaqa (Tati Qola) in Yismala, Gojjam. The remaining E.D.U army came under the leadership of a certain Tezera and entered the Sudan never to return in Semen Ačäfär and Aläfa again. Outraged by the death of her father, Ayalnesh is said to have been joined E.P.R.P. ${ }^{10}$

Furthermore, the political cost in the armed struggle had needed the military building. Thus, one thing what someone bear in mind, the military structure of the E.P.R.P armed force was contain members inclusively from all peoples and nations of Ethiopia including the Nägädä Woyto. Here to confirm it, Demelash was an Agew and Gayim the Tigrayan origin whose family name was Gebre-Egeziyaber serves for a long period of time within the EPRA wings starting from Assimba until the demise of the party in $1991 .^{11}$

Accordingly, the name of the army after the individuals committed to join within the E.P.R.P, all of them dropped their family name and they replaced it with another name based on the fighters' choice. From this point of view, the author of a book entitled as Yassimba Fikir, whose family name is Täsfayä Wäldä Yohanis, but his

\footnotetext{
${ }^{1}$ Andargachew,p. 137.

${ }^{2}$ Wondemeneh,p.9.

${ }^{3}$ Hiwot, p. 138

${ }^{4}$ Curtis Meek \&, Dan Reiter "Determinants of Military Stratagy,1903-1994;A Quantitative Empirical Test," Wiley on behalf of the International Studies association,Vol.43,No.2.,(1999),p.363., access, stable URL:https://www.jstor.org/stable/2600760

${ }^{5}$ RalphL Powell, "Maoist Military Doctrines, " University of California Press, Vol.8.No.4

,(1968),p.239.; Source Stable URL:https://www.jstor.org/stable/2642200

${ }^{6}$ Edwared L.Katrenbach,JJ. And Gene Z. Hanrahant and," Political Science Quarterly, the Revolutionary Strategy of Mao Tse-Tung," Academy of political Science, Vol.70, No.3.,(1955),p.321. ,Access: stable URL:https://www.Jstor.org/stable/2145469.

${ }^{7}$ Informants: Meseret Cherqos, Banch Gize Tadesse Halibu

${ }^{8}$ Genet Ayele, p. 30 .

${ }^{9}$ Informants: Tadesse Woreket, Asfaw Adimasu, Meseret Cherqos, Banch Gize Tadesse, Atinkut.

${ }^{10}$ Informants: Alemu Aseged, Tagele, Atalay.

${ }^{11}$ Wondemeneh,p.37.: Informants: Meseret Cherqos, Atinkut, Halibu, Fikade.
} 
name in the military struggle was Amanuael. ${ }^{1}$ Thus, the armed structure of E.P.R.P was contained both sex and the fighters were after they join delivered the new neck-name. Besides to the above sprit, the construction of widespread defensive works would require fund. In the meantime the student association from North America was supported the

E.P.R.P guerrilla fighters. ${ }^{2}$

China on its part, around 1978 was provided both financial support and tactical training provision to the E.P.R.P. The socialist party of Italy was also one of the E.P.R.P ropes which provided some medicines and certain technical provision. ${ }^{3}$ Consequently, the discontented groups of the E.P.R.P, with the 1974 revolution, in the meantime had been took state properties from state Banks and other governmental institution. ${ }^{4}$

According to the informant, from the commercial Bank of Dangla, the E.P.R.P fighters were once up on a time took about two million Birr per day. ${ }^{5}$ In relation to this concept: in Amharic (Ethiopians' National language) it says as follow:

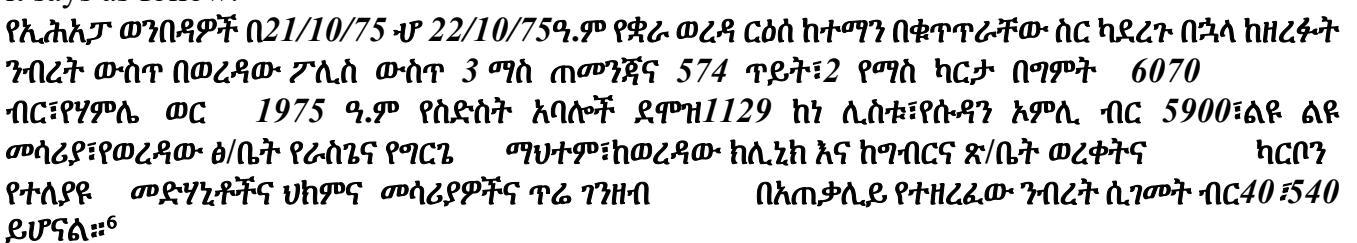
PUPA: $:^{6}$

Lit. It means: "After the E.P.R.P control Qwara wäräda"s city on 30/10/75, they took many armaments

$$
\text { and financial resource including medicines from the government offices }
$$

and store.

$$
\text { It is estimated about totally } 40540 \text { Birr was appropriated." }
$$

The E.P.R.P had also some loyalists in the military council from the Därg "s officials, teachers and physicians and as well as the state of Somalia. ${ }^{7}$ Besides to this, the "Red cross" was also provided a kind of cloth and other materials. ${ }^{8}$ Thus, in the meantime, the party was supported by internal and external kindnesses.

Likewise among other things, the E.P.R.P revolutionary groups were spent their daily food from the people when they were at movement. They well-ordered the people based on their number from five up to ten Enjära (lit. bread) with one Dist wät (lit. one pot of ...) in each house. Sometimes the guerrilla fighters also asked milk and other types of diet. Accordingly, all food types in the E.P.R.P military tradition had eaten by socializing. ${ }^{9}$ In addition to this, the party had been performed widespread agricultural activities in Mahdid, Mätrhad, Shimäl Egire, Därähason, Qäzqäz, Awujäbäl, Aybaza, Abay Dar, Dibh, Gazigie Erefft, Tahsas and Tiha. So, Sorghum, Misre, sesame was some of among common products. Besides to this, honey and sesame were used as commercial product to the Sudan. They also practiced animal husbandry. According to many interviewees, once the party had more than two thousand to three thousand cattle. ${ }^{10}$ Therefore, the E.P.R.P. at first was depending on their daily feeding on the community but latter they attempted to feed themselves.

Correspondingly, one of the political costs in the armed struggle remains the requirement of arming of the soldiers. Besides to this, it was Shabia and Jäbäha which delivered handgun to the E.P.R.P. Apart from the above collections, according to many informants even in 1988, from Mora fortification in Wonbära within the short period of conflict more than three hundred ninety the Drag's soldiers had been captives including their weapons. ${ }^{11}$

Accordingly, in 1990, after short battle in Dälgi the E.P.R.P military wings defeated the Därg and they took many armaments and different utensils from government store and took more than three hundred co-operative bull. $^{12}$

In line with this, the Schools, health centers, police stations had been targeted areas as it remained mentioned above to improve their material demands for education and medical material availability respectively. ${ }^{13}$

Therefore, it was Shabya and Jäbäha that the two prominent allies to the E.P.R.P from the very start. Moreover,

\footnotetext{
${ }^{1}$ Kassay Abirha,p.40.: Informants: Asfaw, Meseret Cherqos, Banch Gize.

${ }^{2}$ Kiflu Tadesse, p. 107.

${ }^{3}$ Kiflu,p.186.: Informant: Kere Gebre Meskel

${ }^{4}$ Kiflu, p. 187.

${ }^{5}$ CGAC: Folder no -file no, Täbätnaäw Silämigägnu Pamplitoch Report, from Yä Gonder Awuraja Kifle Hager Police Memria; Lekifle Hager Astädadär Tsifät Bät; Ref no,18/11/774; qün,17,1969 E.C

${ }^{6}$ Informant: Asmare Addisu, Sinor Tegegne.

${ }^{7}$ CGAC,Folder no, yä 1969 yä- çliga Awurajja report about the E.D.U and E.P.R.P struggle, File no,3305, from Fitawrari Siyum Ejigu the Kifle Hager Astedader, to the çliga Awurajja Astedader, Ref no,5/2267/69,qün 10-12-69.Informants: Halibu, Kere.

${ }^{8}$ Informants: Meseret Cherqos.

${ }^{9}$ Informants: Asfaw: Meseret Cherqos, Banch Gize: Asmare Addisu, Atinkut, Halibu, Engida.

${ }^{10}$ Informants: Asfaw: Meseret Cherqos, Banch Gize: Asmare Addisu, Atinkut, Halibu, Engida

${ }^{11}$ Informants: Tadesse Woreket, Banch Gize, Meseret Cherqos, Asfaw Adimasu, Engida.

${ }^{12}$ Informants: Alemu Aseged, Kere.

${ }^{13}$ Informants: Asfaw Adimasu, Meseret Cherqos, Banch Gize, Asmare Adisu.
} 
a military thinking had an additional question on its foreign policy. Of course, all military policy has been implications for foreign rule since it intended to achieve nationwide objective by the use of foreign policy. ${ }^{1}$

Besides to this, according to Mao "warfare is a form of foreign policy". ${ }^{2}$ Hence, the E.P.R.P on its part had intercontinental relation with the communist chains from the very start". ${ }^{3}$ According to Kiflu Tadesse, there had been the finest relationship among E.P.R.P and china through the E.P.R.P diplomats Shambel Moges, wolide Mikael and the chains E.P.R.P sympathizer Wä. In addition to this, the E.P.R.P had optimistic relation with the North America and Europe since it was organized and fashionable itself in this continent ${ }^{5}$ and the Sudan also provided a kind of medicine and food initially. ${ }^{6}$ Therefore, the E.P.R.P was developed a sort of negotiation with external world.

As we can understand in the military struggle, camps are a decisive requirement. Accordingly, the E.P.R.P guerrilla fighters were established their own military foundations. Among theses, in Aläfa Takusa region in Gazigie; Adiwang, Gujana, Rob Gäbya and Bärmurie were the main camps.

Here, particularly in Gujana, many criminal decisions were left and sentenced to death and up to physical and financial punishment was implemented. Hence,based on the views of many informants, Bärmurie was used to train the E.P.R.P fighters for many times and the general assemblies were takes place by sacrifices from four up to five bulls at this place. Among these, in Aläfa Takusa region in Gazigie; Adiwang, Gujana, Rob Gäbya and Bärmurie were the main camps. Here, particularly in Gujana, many criminal decisions were left and sentenced to death and up to physical and financial punishment was implemented. Hence, based on the views of many informants, Bärmurie was used to train the E.P.R.P fighters for many times and the general assemblies were takes place by sacrifices from four up to five bulls at this place. ${ }^{7}$

Consequently, Rob Gäbya was also one of a place that the E.P.R.P took place many time the general assembly. According to my interviewees, "if the tree can speak it can give us much more information about the political teaching and E.P.R.P's ant- Därg propaganda initiative doings." The other area was Käbtäle, which remained one of the biggest camps located far from Gazigie around the border areas of Benishangul region. ${ }^{8}$

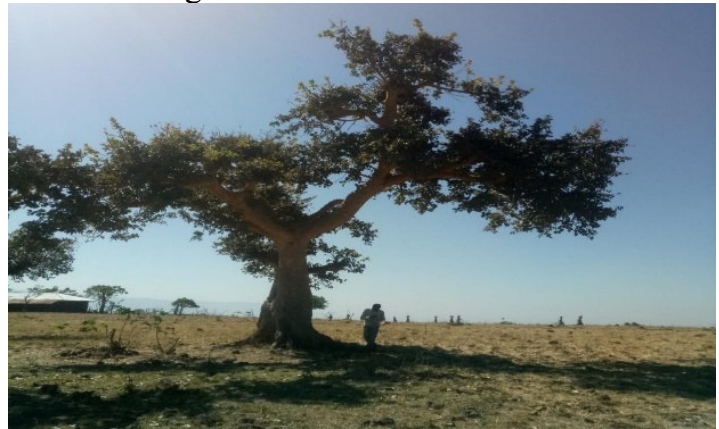

Photo 1: the Bamba (Adansoniadigitata), tree, in Rob Gebya which had been served as the office to the E.P.R.P, a photo taken by the researcher on 10/02/2020.

Added to the above places, in Aläfa Takusa wäräda in the qolla Takusa region it was Konta that many suspected criminals were punished. As many interviewees have illustrated, even without any cross examination, they were suffered and punished in-kind individuals in thise specific place. ${ }^{9}$ Consequently, these all are depicted the E.P.R.P guerrilla fighters were creating permanent camps in Aläfa Takusa wäräda in general.

Beginning from the 1970s, when the political faction cropped up between the E.P.R.P and T.P.L.F in particular and E.P.L.F in general, it remained Qwara which had been chosen as the second Assimba with the E.P.R.P. Therefore, in Qwara the E.P.R.P had been established their camps in Shimel Egire, Delegu, Derahason, Banbuha wuha, Agame wuha, Mugechit, Shinfa, Tahsas, Abamendi, Mahdid, Metrhad, Saliya, Kuza, Bakusa, Ayma, Tihua and Tiha. Among these places, Mahdid, Shimel Egire, Ayma and Tahsas were the place where the

E.P.R.P took annual conference so as to takes place re-assessment program about two times a year. ${ }^{10}$

Though, in the most remote place in Abamendi, they had been establish Radio station which remains still

\footnotetext{
RalphLPowell, “Maoist Military Doctrines,” University of California Press ,Vol.8 .No.4, (1968):248.; access URL:https://www.jstor.org/stable/2642200

${ }^{2}$ Ibid, p, 248

${ }^{3}$ Ibid, p, 248.

${ }^{4}$ Kiflu, p.184.

${ }_{5}^{5}$ Merera, p.8

${ }^{6}$ CGAC, Folder no 5,fiel no,yä-1975 yä çliga Awurajja Mätsatsafia dosie,Sile wänbediewoch Enqisiqasie yä 24 sihat yä tsetita report,from çliga Awuraja to colonel Aklilu Mulugeta the chief Commander, Ref no 002/623/75, date hamlie 1 qän 1975.

${ }^{7}$ Informants: Wolelaw Beyene, Meseret Cherqos, Asfaw Addisu, Sherbew Alene, Tagele.

${ }^{8}$ Informant: Wolelaw, Asfaw Adimasu, Abeje Alemu; Sherbew, Tagele.

${ }^{9}$ Informants: Abeje Alemu, Tadilo Bere, Abich, Abie Alemu.

${ }^{10}$ CGAC,Folder no,5, fiel no, yä 1975 yä- çliga Awurajja metsatsafia dose,from Asefa Mekonen yä Gondar kifle Hager vice Astädadär to the kifle Hager Astädadär office.: Informants: Asfaw Adimasu, Meseret Cherqos, Atinkut, Halibu, Engida.
} 
reserved and no one cannot entered because the peoples perceive as there is evil spirit that put by the E.P.R.P members to kept it. ${ }^{1}$ Therefore, the E.P.R.P had been established the main camps in Qwara. For any revolutionary warfare, it remains necessary to emphasis on the point that military operation and training are as an energetic element. Accordingly, the E.P.R.P on its part also had the military training place most dominantly in Qwara such as Wärkit, Shimäl Egirä, Aläti, Qäziqäz, Tahsas, Altish, Jäbay, Mätrhad, Därahason and Jäbäl Siquar in Tiha.

Among these training places, wärkit was the most strategic which has a half moon shape mountains area in the east direction. ${ }^{2}$ As many of my interviewees illustrated, the duration of training also acquired from three to six months. The training structure also focused on the physical endurance, political teaching and the way on how to applied guerrilla Armed struggle. ${ }^{3}$ Hence, the E.P.R.P guerrilla troops had constant training places in the study area.

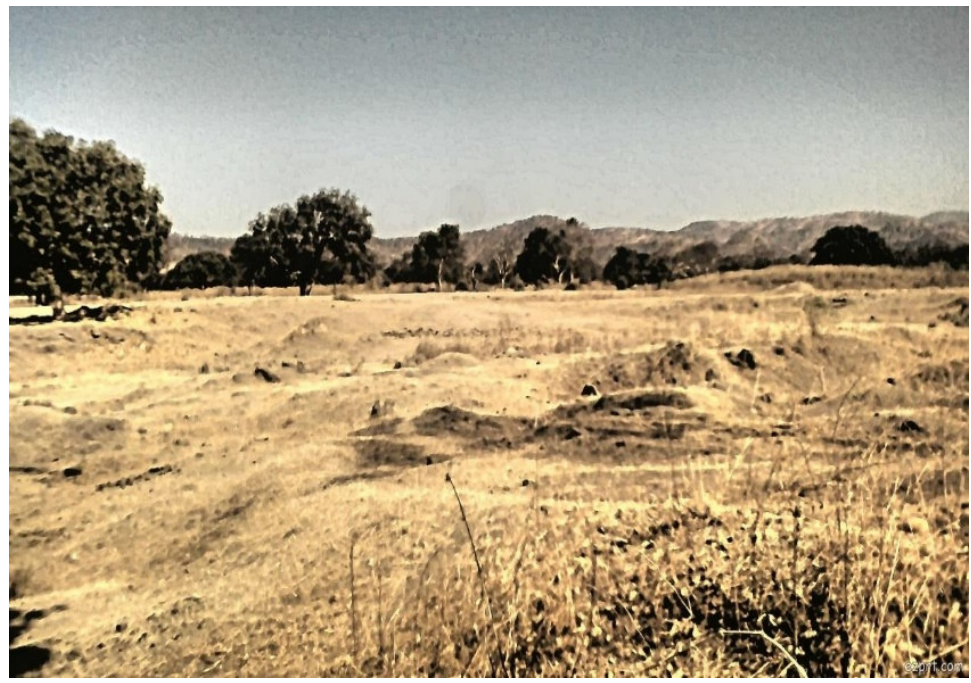

Photo 2: Workit, the main training center of E.P.R.P in Qwara; a photo taken by the researcher on 16$17 / 12 / 2020$.

In line with the above ideas, it remains meaningful knowing about the armed style and armament accessibility of the enemy camps. Consequently, the E.P.R.P on its part had been developed its own system of intelligence. Besides to this, among the methods they used, assimilating themselves with the communities, acting as a priest and even they also associated themselves with the enemy solider and if it stands obtainable sometimes they used their rival military cod were some of the methods. ${ }^{4}$ In relation to this, there were also some individuals from the Därg who were provided essential material evidence to the E.P.R.P. ${ }^{5}$ Therefore, before the movement the E.P.R.P was searching and analyzing the qualification of its antagonistic groups.

In the military science, beyond the readiness of modern weapons and decent equipment's, the military arrangement in the group during the periodic war remains an indispensable element. Due to this fact, in order to evangelizing the people on a place where they arrive it was the kiflä hizib (Lit. part of people) which teaches about their military doctrine and to made good relationship between the societies and E.P.R.P military wings. In line with this, the additional groups which were well-thought-out as a special force during the time of war and which played the provocative system of war were the squad. It ranged mathematically from five to seven. Consequently, the Hayle and Colum were also other system of group which contained from twenty five up to thirty and thirty to ninety individuals respectively. The other groups were Budin that comprises from fifteenth to twenty five fighters. The other collection was the team which covers about five to twenty five person. ${ }^{6106}$ Therefore, the military organization and rearrangement had been the great concern for the E.P.R.P armed struggle in the time of war.

\section{REFERENCES}

Andargachew Tiruneh. The Ethiopian Revolution; 1974-1987.Cambridge: Cambridge University press. 1993. Aragawi Berehe. A Political History of the Tigray peoples Libration Front 1975- 1991.

VRIJE: VERJE University press.2008.

Bahru Zewude. A History of Modern Ethiopia; 1855-1974.Addis Abeba: Addis Abeba University press.1991. A Short History of Ethiopia and the Horn. Addis Abeba: Addis Abeba University press. 1998.

\footnotetext{
${ }^{1}$ Informants: Atinkut, Halibu, Engida.

${ }^{2}$ Informants: Tadesse Woreket, Wolelaw, Asfaw Adimasu, Meseret Cherqos, Banch Gize, Asmare Adisu.

${ }^{3}$ Ibid.

${ }^{4}$ Ibid.

${ }^{5}$ Informant: Kere, Banch Gize, Meseret Cherqos.

${ }^{6}$ Informants: Tadesse Woreket, Wolelaw, Asfaw Adimasu, Meseret Cherqos, Banch Gize, Kere, Asmare Adisu.
} 
Clapham, Christopher. Mängistu Haylämariam and the Revolution. Addiss Abeba: Addis Abeba University press.2009.

Colonel Mengistu Haylemariam.Tiglachin. Thähay: Tsähay printing press.2012.

Gebru Tareke. Ethiopian: power and protest: Cambridge: Cambridge University press.1991.

Genet Ayele. Yälätnal Colonial Mängistu Haylämariam Tizitawoch. Mega: Mega printing press.2002.

Gerima Tafere. Gändärie Bägashaw. Addis Abeba: Addis Addis Abeba University press.1957.

Hiwot Tefera. Tower in the Sky. Addis Abeba: Addis Abeba University press.2012.

Kassay Abirha. Yasimba Fiqir. Tesfaye Woldeghiorghis: Tesfaye Woldeghiorghis printing press. 2013.

Kiflu Tadesse. Yatiwuläd yäläwut Maäbäl Bä Ethiopia. 2001.

Marcus, Harold G. A History of Ethiopia. California: California University press.1994.

Medhane Tadesse. Turing conflicts to cooperation in the Horn of Africa. Addis Ababa: Addis Ababa University Press.2004.

Merera Gudina. Party politics, political polarization and the future Ethiopian Democracy. International conference on African Development Archive. International conference on African Development Archive.2007.

Wondwosen Teshome. Ethiopian opposition political parties and Rebel fronts; past and present. World Academy of Science Engineering Technology. World Academy of Science Engineering Technology press.2009.

Zenebe Feleke. Ethiopian people's Revolution and the Därg Jun 1974 to September, 1981- 2015. 